\title{
Platelet-rich plasma: everything new may not be good enough!
}

\author{
Trombositten zengin plazma: Her yeni şey yeterince iyi olmayabilir!
}

\author{
O. Şahap Atik, MD \\ Department of Orthopedics and Traumatology, Medical Faculty of Gazi University, Ankara, Turkey
}

Platelet-rich plasma (PRP) is obtained from a patient's own peripheral blood, after centrifuging it, and has growth factors. ${ }^{[1]}$

There are clinical studies indicating that PRP therapy may enhance muscle or tendon healing, and accelerate tissue regeneration after musculoskeletal injuries such as strain or contusion, during sports activities. $^{[2]}$ It is also used for the treatment of

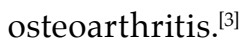

However, no definitive conclusions can be made about the effects of PRP in those conditions, because most studies are of low to moderate methodological quality and use variable PRP protocols. There is a growing debate regarding PRP's clinical efficacy, the timing of PRP administration, optimal platelet concentration, platelet separation technique, and ideal volume of the platelet concentrate. ${ }^{[4,5]}$

Uncontrolled studies have shown beneficial effects for several conditions. Whereas results of controlled trials comparing PRP with standard therapies are not as definitive. ${ }^{[4-6]}$

The results of a study of Yan et al ${ }^{[7]}$ indicate that the efficacy of the PRP treatment of tendinopathy varies markedly with different types of PRP preparations; leukocyte-poor-PRP may promote tendon healing through anabolic effects while leukocyte-richPRP may impair the repair process. They suggest that leukocyte-poor-PRP administration might be a favorable option for the clinical management of chronic tendinopathy in the future.

Also, whether locally applied PRP injections are more effective than a surgical procedure in reducing symptoms is still controversial. ${ }^{[8,9]}$

It is far too early to draw conclusions about the efficacy of PRP as a treatment for all these conditions.
Further high-quality research is needed to establish the clinical and cost-effectiveness of PRP, and the optimal PRP protocol.

Orthopaedic surgeons should be aware of that there is still uncertainty about the evidence behind PRP therapies, and should inform patients about this fact.

\section{REFERENCES}

1. Paoloni J, De Vos RJ, Hamilton B, Murrell GA, Orchard J. Platelet-rich plasma treatment for ligament and tendon injuries. Clin J Sport Med 2011;21:37-45.

2. Taylor DW, Petrera M, Hendry M, Theodoropoulos JS. A systematic review of the use of platelet-rich plasma in sports medicine as a new treatment for tendon and ligament injuries. Clin J Sport Med 2011;21:344-52.

3. Bennell KL, Hunter DJ, Paterson KL. Platelet-Rich Plasma for the Management of Hip and Knee Osteoarthritis. Curr Rheumatol Rep 2017;19:24.

4. Sheth U, Simunovic N, Klein G, Fu F, Einhorn TA, Schemitsch E, et al. Efficacy of autologous platelet-rich plasma use for orthopaedic indications: a meta-analysis. J Bone Joint Surg [Am] 2012;94:298-307.

5. Mazzocca AD, McCarthy MB, Chowaniec DM, Cote MP, Romeo AA, Bradley JP, et al. Platelet-rich plasma differs according to preparation method and human variability. J Bone Joint Surg [Am] 2012;94:308-16.

6. Andia I, Sánchez M, Maffulli N. Platelet rich plasma therapies for sports muscle injuries: any evidence behind clinical practice? Expert Opin Biol Ther 2011;11:509-18.

7. Yan R, Gu Y, Ran J, Hu Y, Zheng Z, Zeng M, et al. Intratendon Delivery of Leukocyte-Poor Platelet-Rich Plasma Improves Healing Compared With Leukocyte-Rich Platelet-Rich Plasma in a Rabbit Achilles Tendinopathy Model. Am J Sports Med 2017;45:1909-1920.

8. Field LD. Editorial Commentary: The Needle or the Knife? Platelet-Rich Plasma Versus Surgery for Lateral Epicondylitis. Arthroscopy 2017;33:1330-1331.

9. Atik OŞ. Do we surgeons perform surgery only? Eklem Hastalik Cerrahisi 2016;27:123-4.

\footnotetext{
- Correspondence: O. Şahap Atik, MD. Gazi Üniversitesi Tıp Fakültesi Ortopedi ve Travmatoloji Anabilim Dalı, 06500 Beşevler, Ankara, Turkey. Tel: +90 312 - 2025528 e-mail: satikmd@gmail.com
} 